\title{
Synthesis of B Vitamins by Excised Parts of White Lupine Seedlings Grown in Sterile Culture ${ }^{1}$
}

\author{
Felix G. Gustafson
}

From the Department of Botany, University of Michigan, Ann Arbor, Michigan Received January 19, 1954

\section{INTRODUCTION}

In the thirties and early forties, numerous investigations were made on the vitamin requirements for growth of excised roots, stem tips, leaf sections, and embryos. As these experiments have been thoroughly reviewed by Bonner and Bonner (1), Robbins (2), and White (3), they will not be discussed here. If, in these experiments, the addition of a vitamin to the nutrient culture increased the growth, it was presumed that this vitamin was needed by the plant under consideration, and that the explants did not synthesize enough for their needs. If, on the other hand, there was no increase in growth, when a particular vitamin was supplemented to the medium, there were two explanations open to the investigator. Either this vitamin was not required for the growth process, or the plant synthesized enough of the vitamin for its needs. Direct determination of vitamin synthesis by excised roots have also been made. These investigations showed the synthesis of thiamine by pea roots (4), riboflavin by roots of tomato, clover, alfalfa, sunflower, and Datura (5), and ascorbic acid by tomato roots (6).

The purpose of this investigation has been to extend the knowledge of the ability of excised plant parts to synthesize thiamine, riboflavin, and niacin from the simple organic compounds, sucrose and glycine, and inorganic compounds, when grown in sterile culture.

\section{Methods and Materialis}

White lupine seedlings had been used previously in experiments on vitamin synthesis and they were, therefore, chosen again as the plants to be studied. The

1 Paper from the Department of Botany, University of Michigan, No. 1000. This investigation has been financially aided by the U. S. Public Health Service. 
roots, hypocotyls, and epicotyls (that part of the seedling which is above the cotyledons) were used.

To prepare sterile seedlings for excision, dry, uniform seeds were sterilized for 15 min. in $20 \%$ Chlorox $(0.25 \%$ sodium hypochlorite) solution and then placed in sterile distilled water in 6 -in. Petri dishes, to soak for $12 \mathrm{hr}$. The excess water was poured off, and the dishes were placed in a dark room at $23-24^{\circ} \mathrm{C}$. and left there for 7 days, or a shorter time if roots were to be used. The seeds were soaked in a large volume of water after sterilization to enable the seed coats to slip off easily as the seedlings enlarged. When this procedure was not followed, the seed coats remained firmly attached to the cotyledons, and the epicotyls could not readily be excised.

The excision and transfer to culture flasks was carried out in a sterile transfer chamber. Usually seven pieces of the desired part of the seedling were placed in a 500 -ml. Erlenmeyer flask. Both liquid and agar media were tried, but in later experiments, liquid cultures were employed exclusively. White's basal medium (7) was modified by substituting the minor elements used by Nitsch (8). The vitamins under investigation were, of course, left out of the solution. One hundred milliliters of solution was used per flask. The concentration of agar was $0.5 \%$.

The conditions of culturing were quite varied and will be mentioned as the occasion arises. In general, the culture flasks were kept in a laboratory, but sometimes in a dark room adjoining the laboratory. The temperature was quite constant at $23-24^{\circ} \mathrm{C}$. in the dark room, but the laboratory temperature varied more. The flasks were stoppered with cotton plugs which were covered with caps of aluminum foil. Contamination with bacteria or fungi was very rare. Tests for contamination were made both by staining and culturing methods.

Thiamine and riboflavin analyses were those of Connor and Straub (9) as modified for plant material by the writer (10). The niacin assay followed the prescribed procedure as given in the Methods of Vitamin Assay issued by the Association of Vitamin Chemists (11).

In his investigations on vitamins, the writer has usually calculated the vitamin content in micrograms per gram fresh weight. In the experiments under consideration, it was soon learned that the growth eonsisted largely of an increase in water and not so much an increase in dry material. Therefore, if the previous practice of calculating the vitamin content on the basis of fresh weight was followed it would be misleading. When this was realized, it was decided to calculate the vitamin content per explant before and after culturing. Any gain in vitamin content of the sample after culturing over the original sample indicated synthesis.

\section{Results}

The results of these experiments are shown in Tables I, II, and III. With few exceptions, there is an increase in riboflavin, thiamine, and niacin content per explant during the in vitro culturing. The few negative or low positive values can be explained by poor selection of the material at the beginning of the experiment. The per cent gained is quite varied in the different experiments. This difference is probably due to the difference in the stage of development at the time of making ex- 


\section{TABLE I}

Synthesis of Vitamins by Excised Hypocotyls of White Lupine When Cultured in White's Solution

Figures denote micrograms of vitamin per hypocotyl before and after culturing.

\begin{tabular}{|c|c|c|c|c|c|c|c|c|c|}
\hline \multirow{2}{*}{$\begin{array}{l}\text { Expt. } \\
434\end{array}$} & \multicolumn{2}{|c|}{$\begin{array}{l}\text { Fresh wt. in } \\
\text { g./hypocotyl } \\
\text { before and after } \\
\text { culturing }\end{array}$} & \multicolumn{2}{|c|}{$\begin{array}{c}\text { Riboflavin } \\
\text { before and after } \\
\text { culturing }\end{array}$} & \multicolumn{2}{|c|}{$\begin{array}{c}\text { Thiamine } \\
\text { before and } \\
\text { after culturing }\end{array}$} & \multicolumn{2}{|c|}{$\begin{array}{l}\text { Niacin before } \\
\text { and after } \\
\text { culturing }\end{array}$} & \multirow{2}{*}{ Liquid-light } \\
\hline & 0.45 & 0.77 & 0.29 & 0.35 & 0.76 & 0.77 & 2.92 & 3.43 & \\
\hline 437 & & 0.4 & 0.27 & & 0.54 & 0.6 & 2.40 & 2.87 & Liquid-light \\
\hline 440 & 0.38 & 0.66 & 0.34 & 0.41 & 0.78 & 0.79 & 2.61 & 3.15 & Liquid-light \\
\hline 464 & 0.61 & 1.53 & 0.41 & 0.46 & 0.91 & 0.95 & 4.12 & 3.52 & Agar-dark \\
\hline 466 & 0.34 & 0.50 & 0.22 & 0.31 & 0.50 & 0.72 & 1.68 & 2.36 & Agar-dark \\
\hline 472 & 0.33 & 0.59 & 0.30 & 0.38 & 0.59 & 0.61 & 2.63 & 2.41 & Agar-diff. light \\
\hline
\end{tabular}

TABLE II

Synthesis of Vitamins by Excised Epicotyls of White Lupine When Cultured in White's Solution

Figures denote micrograms of vitamin per epicotyl before and after culturing.

\begin{tabular}{|c|c|c|c|c|c|c|c|c|c|}
\hline \multirow{2}{*}{$\begin{array}{r}\text { Expt. } \\
434\end{array}$} & \multicolumn{2}{|c|}{$\begin{array}{l}\text { Freslı wt. in } \\
\text { g./epicotyl } \\
\text { before and after } \\
\text { culturing }\end{array}$} & \multicolumn{2}{|c|}{$\begin{array}{l}\text { Riboflavin } \\
\text { before and after } \\
\text { culturing }\end{array}$} & \multicolumn{2}{|c|}{$\begin{array}{l}\text { Thiamine } \\
\text { before and after } \\
\text { culturing }\end{array}$} & \multicolumn{2}{|c|}{$\begin{array}{l}\text { Niacin before } \\
\text { and after } \\
\text { culturing }\end{array}$} & \multirow{2}{*}{$\underbrace{\begin{array}{c}\text { Condition of } \\
\text { experiment }\end{array}}_{\text {Liquid-light }}$} \\
\hline & 0.05 & 0.09 & 0.10 & 0.19 & 0.09 & 0.08 & 0.57 & 0.73 & \\
\hline 437 & 0.09 & 0.35 & 0.19 & 0.48 & 0.25 & 0.31 & 0.97 & 2.47 & Liquid-light \\
\hline 440 & 0.04 & 0.17 & 0.13 & 0.29 & 0.14 & 0.19 & 0.63 & 1.08 & Liquid-light \\
\hline 451 & 0.10 & 0.24 & 0.18 & 0.31 & 0.23 & 0.35 & 1.01 & 1.44 & Agar-light \\
\hline 464 & 0.04 & 0.12 & 0.06 & 0.15 & 0.07 & 0.12 & 0.38 & 0.64 & Agar-dark \\
\hline 508 & 0.06 & 0.23 & 0.12 & 0.20 & 0.19 & 0.27 & 0.62 & 1.56 & $\begin{array}{l}\text { Liquid-shaker- } \\
\text { dark }\end{array}$ \\
\hline
\end{tabular}

cisions. Even when the seedlings were of the same chronological age, they were not always of the same physiological age. This is easily borne out by the difference in the original values of the explants.

When it became evident that the most accurate way of recording the results was to determine the vitamin content per explant rather than per gram, several experiments were set up in which selections were made in duplicates. These duplicate determinations, in general, agreed within a few per cent, and it is considered that this method of presenting the results is accurate.

Once it was definitely established that excised parts of White lupine 


\section{TABLE III}

Synthesis of Vitamins by Excised Roots of White Lupines When Cultured in White's Solution

Figures denote micrograms of vitamin per root before and after culturing.

\begin{tabular}{c|c|c|c|c|c|c|c|c|c|}
\hline \hline Expt. & $\begin{array}{c}\text { Fresh wt. in } \\
\text { g./root before } \\
\text { and after } \\
\text { culturing }\end{array}$ & $\begin{array}{c}\text { Riboflavin } \\
\text { before and after } \\
\text { culturing }\end{array}$ & $\begin{array}{c}\text { Thiamine } \\
\text { before and after } \\
\text { culturing }\end{array}$ & $\begin{array}{c}\text { Niacin before } \\
\text { and after } \\
\text { culturing }\end{array}$ & $\begin{array}{c}\text { Condition of } \\
\text { experiment }\end{array}$ \\
\hline 472 & 0.10 & 0.42 & 0.18 & 0.55 & 0.25 & 0.37 & 1.03 & 2.18 & Sol. dif. light \\
476 & 0.11 & 0.29 & 0.20 & 0.49 & 0.27 & 0.64 & 0.83 & 1.35 & Agar-dark \\
477 & 0.13 & 0.30 & 0.20 & 0.20 & 0.29 & 0.43 & 1.05 & 1.49 & Sol. dark \\
480 & 0.12 & 0.29 & 0.21 & 0.26 & 0.23 & 0.25 & 1.17 & 1.27 & Sol. dark \\
501 & 0.19 & 0.33 & 0.25 & 0.28 & 0.35 & 0.38 & 1.39 & 1.39 & Sol. dark \\
502 & 0.15 & 0.27 & 0.25 & 0.32 & - & - & 1.23 & 1.07 & Sol. dark \\
\hline
\end{tabular}

seedlings synthesized riboflavin, thiamine, and niacin in sterile cultures, a few experiments were set up to study conditions influencing this synthesis. It was found, in cultures placed on a reciprocal shaking apparatus, that in 3 days on a shaker as much vitamin was produced as with stationary cultures in 9 days. This increased synthesis with agitation could be due to aeration and/or to a closer contact with the nutrient medium.

A shaker large enough to take care of a whole experiment was not available and a substitute had to be found. Sterilized compressed air and nitrogen were passed through a train of Erlenmeyer flasks to aerate and agitate the solutions. The flasks were fitted with two side arms, the inlet tube extending to the bottom of the flask. The compressed air and nitrogen were sterilized by being passed through sinteredglass tubes extending into $12 \mathrm{~N} \mathrm{H}_{2} \mathrm{SO}_{4}$ solution and then washed in distilled water. Precautions were taken to prevent contamination during the assembling of the sterilized flasks. Contaminations were very infrequent and all septic cultures were discarded.

Several experiments, two of which are recorded in Table IV, were run in which nitrogen or air was bubbled through the nutrient solution containing the epicotyls. In both of the experiments, one train of flasks receiving either nitrogen or air was covered with black paper, while the others were exposed to the weak light (15-20 ft.-candles) of the laboratory. A control with no aeration accompanied each experiment.

The aeration increased the riboflavin and niacin concentration, but it is doubtful whether it had any effect on thiamine. Nitrogen decreased the concentration of all three vitamins. This decrease was probably due to lack of synthesis and continued utilization during the metabolism of the plant. How the oxygen might function is not shown in these experi- 
TABLE IV

Influence of Bubbling Air or Nitrogen Through White's Solution on Riboflavin, Thiamine and Niacin Content of Epicotyls of White Lupines

Figures denote micrograms per piece of epicotyl.

\begin{tabular}{|c|c|c|c|c|c|c|c|c|c|c|}
\hline \multirow{2}{*}{ Expt. } & \multirow{2}{*}{$\begin{array}{l}\text { Light } \\
\text { conditions }\end{array}$} & \multicolumn{3}{|c|}{ Riboflavin } & \multicolumn{3}{|c|}{ Thiamine } & \multicolumn{3}{|c|}{ Niacin } \\
\hline & & No aer. & Aeration & Nitrogen & No aer. & Aeration & Nitrogen & No. aer. & Aeration & $\underset{\text { gen }}{\text { Nitro- }}$ \\
\hline 482 & Light & 0.143 & 0.308 & 0.045 & 0.238 & 0.220 & 0.039 & 0.777 & 1.291 & 0 \\
\hline 484 & Light & 0.119 & 0.231 & 0.024 & 0.141 & 0.222 & 0.017 & 0.932 & 1.443 & 0.106 \\
\hline 482 & Dark & 0.143 & 0.245 & 0.015 & 0.238 & 0.222 & 0.035 & 0.777 & 0.903 & 0 \\
\hline 484 & Dark & 0.119 & 0.223 & 0.021 & 0.141 & 0.166 & 0.015 & 0.932 & 1.073 & 0.075 \\
\hline
\end{tabular}

TABLE V

Influence of Light on the Synthesis of Vitamins by Excised Epicotyls of White Lupines in vitro

Figures denote micrograms per epicotyl.

\begin{tabular}{ccccl} 
Expt. & Riboflavin & Thiamine & Niacin & \multicolumn{1}{c}{ Light intensity } \\
492 & 0.240 & 0.174 & 1.165 & Darkness \\
& 0.221 & 0.211 & 1.495 & $10-15 \mathrm{ft}$. -candles \\
& 0.241 & 0.165 & 1.585 & $50-80 \mathrm{ft}$. -candles \\
493 & 0.281 & 0.182 & 1.435 & $100-150 \mathrm{ft.}$-candles \\
& 0.125 & 0.165 & 1.36 & Darkness \\
& 0.269 & 0.234 & 1.29 & $10-15 \mathrm{ft}$. -candles \\
& 0.310 & 0.201 & 1.44 & $50-80 \mathrm{ft}$. candles \\
497 & 0.353 & 0.205 & 1.56 & $100-150 \mathrm{ft.candles}$ \\
& 0.345 & 0.251 & 1.24 & Darkness \\
& 0.373 & 0.184 & 1.18 & $10-15 \mathrm{ft}$. -candles \\
& 0.338 & 0.180 & 1.22 & $50-80 \mathrm{ft}$-candles \\
& 0.484 & 0.229 & 1.48 & $100-180 \mathrm{ft}$. -candles
\end{tabular}

ments, but as its absence is equally inhibitory with all vitamins, it might be assumed that oxygen functions in aerobic respiration and that vitamin synthesis is therefore associated with aerobic respiration. The low light intensity in these experiments seemed to be sufficient to enhance the niacin synthesis when the tissue was aerated, and the same is probably true for riboflavin but not for thiamine. Under nonaerated conditions, the light was without effect.

In the above experiments, there is evidence as just mentioned, that light might influence the synthesis of niacin and riboflavin. Several experiments in which the light intensity was varied from 0 to $180 \mathrm{ft}$.-candles were set up. Four trains of ten 
flasks each were placed parallel to one another. Black cardboard was placed across the series of flasks so that five compartments were formed, each containing eight or more flasks. Each compartment had different light intensities, but the same temperature.

Light intensity of the value of 100-180 ft.-candles does increase the synthesis of riboflavin and niacin, but the influence of the lower light intensities is doubtful (Table V). That the increase may be due to photosynthesis in the green explants is suggested by some experiments with roots, where there was a definite decrease of riboflavin at the higher light intensities. There is no relation between the thiamine content and light intensity.

\section{Discussion}

From the abundant indirect evidence and that obtained by analysis of the particular vitamin, it is becoming evident that other parts than green leaves and stems are able to synthesize the $\mathbf{B}$ vitamins. In this investigation, it has been demonstrated that roots and hypocotyls without chlorophyll and epicotyls, which were green only when grown in light, produced vitamins. This makes it evident that the process is not associated with photosynthesis.

Agitating the culture solution either by placing the flasks on a shaker or by bubbling sterile compressed air through the solution greatly increased the rate of synthesis of riboflavin and to a lesser extent that of niacin and thiamine. Agitating the solution with nitrogen, on the other hand, not only did not increase the vitamin content, but actually decreased it greatly for all three. The explants in the nitrogen cultures made no growth, but in appearance they were normal although small. The presence of oxygen is then an essential factor in the synthesis of thiamine, riboflavin, and niacin by the explants from White lupine seedlings when grown in vitro.

\section{SUMmarY}

In this investigation it has been found that excised roots, hypocotyls, and epicotyls of White lupine seedlings synthesize thiamine, riboflavin, and niacin when grown in sterile cultures. Oxygen is necessary for this synthesis.

\section{REFERENCES}

1. Bonner, J., And Bonner, H., Vitamins and Hormones 6, 225 (1948).

2. Roввins, J., "Plant Growth Substances," p. 463. University of Wisconsin, Madison, Wisconsin, 1951. 
3. White, R., Ann. Rev. Plant Physiol. 2, 231 (1951).

4. Bonner, J., And Buchman, E. R., Proc. Natl. Acad. Sci. U. S. 24, 341 (1938).

5. Bonner, J., Botan. Gaz. 103, 581 (1942).

6. Reid, M. E., ANd RobBins, W. J., Science 95, 632 (1942).

7. White, P. R., "A Handbook of Plant Tissue Culture." Ronald Press Co., New York, 1943 .

8. Nitsch, J. P., Am. J. Botany 38, 566 (1951).

9. Connor, R. T., and Straub, G. J., Ind. Eng. Chem., Anal. Ed. 13, 385 (1941).

10. Gustrayson, F. G., Plant Physiol. 22, 620 (1947).

11. Association of Vitamin Chemists, "Methods of Vitamin Assay." Interscience Pub. New York, 1947. 